\title{
Effect of Techniques and Time of Sowing, Seed Rate, and Weed Management on Selected Herbaceous Legumes Establishments in East Nusa Tenggara, Indonesia
}

\author{
Kana-Hau D, Nulik J \\ East Nusa Tenggara Assessment Institute for Agricultural Technology \\ Jl. Tomor Raya km.32, Naibonat, Kupang, East Nusa Tenggara \\ E-mail: debora_nulik@yahoo.com \\ (received 18-05-2016; revised 19-08-2016; accepted 06-09-2016)
}

\begin{abstract}
ABSTRAK
Kana-Hau D, Nulik J. 2016. Pengaruh dari teknik dan waktu menabur, tingkat benih dan pengelolaan gulma pada perusahaan kacang herba terpilih di Nusa Tenggara Timur, Indonesia. JITV 21(3): 159-164. DOI: http://dx.doi.org/10.14334/jitv.v21i3.1586

Suatu seri penelitian cara dan waktu tanam dan manajemen gulma bagi beberapa species tanaman pakan leguminosa herba terpilih (Clitoria ternatea cv Milgarra, Centrosema pascuorum cv Cavalcade dan cv Bundey, dan Lablab purpureus cv Highworth) telah dilakukan di Nusa Tenggara Timur (Timor dan Flores) untuk mendapatkan cara dan waktu tanam dan manajemen gulma terbaik, yaitu antara lain menghemat tenaga kerja dan memberikan produksi biomassa yang memadai sesuai dengan potensi spesies yang diteliti. Perlakuan cara tanam meliputi tugal, garit (ditutup dan tidak ditutup), dan sebar (digaru dan tidak digaru); dan waktu tanam yang meliputi awal musim hujan (Desember-Januari), pertengahan musim hujan (FebruariMaret) dan akhir musim hujan (April-Mei), serta manajemen gulma dengan menyiang atau tanpa menyiang. Penelitian menggunakan rancangan acak berblok dengan 4 ulangan dirancang dalam plot-plot ukuran $3 \times 4 \mathrm{~m} \mathrm{~s} / \mathrm{d} 4$ x $5 \mathrm{~m}$, bergantung pada ketersediaan lahan untuk penelitian. Hasil penelitian menunjukkan bahwa cara tanam terbaik dengan populasi tanaman tertinggi (42 tanaman $/ \mathrm{m}^{2}$ pada minggu ke 4 setelah tanam) dan produksi biomassa terbesar dipeoleh pada cara tugal (1,75 s/d 2,5 ton BK/ha per panen pada 12 minggu setelah tanam di Ende dan 4-5 ton BK/ha di Nagekeo), diikuti oleh cara tanam digarit tutup (11,3 ton BK/ha di Ende dan 3,5-4 ton BK/ha di Nagekeo), dan terendah pada cara sebar (9-20 tanaman/ $/ \mathrm{m}^{2}$ dan produksi biomassa 2-2,5 ton BK/ha di Nagekeo dan 0,5-1 ton BK/ha di Ende pada panen tanaman umur 12 minggu). Manejemen gulma pada leguminosa menunjukkan bahwa penyiangan nyata memberikan produksi biomasa yang lebih tinggi dibandingkan dengan tanpa penyiangan. Nampak pula bahwa pengaruh gulma lebih besar pada spesies Clitoria ternatea dibandingkan dengan pada spesies Lablab purpureus, terutama pada penanaman awal musim hujan.
\end{abstract}

Kata Kunci: Leguminosa Herba, Clitoria ternatea, Centrosema pascuorum, Lablab purpureus, NTT, Cara Tanam, Waktu Tanam, Establishment

\section{ABSTRACT}

Kana-Hau D, Nulik J. 2016. Effect of techniques and time of sowing, seed rate, and weed management on selected herbaceous legumes establishments in East Nusa Tenggara, Indonesia. JITV 21(3): 159-164. DOI: http://dx.doi.org/10.14334/jitv.v21i3.1586

A series of experiments on techniques and time of sowing, and weed management of legumes Clitoria ternatea cv Milgarra, Centrosema pascuorum cv Cavalcade and cv Bundey, and Lablab purpureus cv Highworth, was conducted in East Nusa Tenggara (in the islands of Timor, Flores, and Sumba) in order to determine proper technique and time of sowing and weed management, which would be efficient in labor use and sufficient biomass production. Treatments of sowing techniques included dibble, furrow (covered and not covered), and broadcast (harrowed and not harrowed); while sowing time consisted of early wet season (December-January), mid of wet season (February-March) and the end of wet season (April-May), while weed managements consisted of weeded and unweeded treatments. The experiments employed block randomized design with four replications using plot sizes of $3 \times 4 \mathrm{~m}$ to $4 \times 5 \mathrm{~m}$, depending on the availability of land for the experiments. The results of the experiments showed that the best sowing technique with the highest plant population at 4 weeks after planting was dibbling (42 plants $\left./ \mathrm{m}^{2}\right)$, followed by furrow, while the lowest plant population was obtained at the broadcast technique $\left(9-20 \mathrm{plants} / \mathrm{m}^{2}\right)$. Similarly, the highest biomass production was obtained in the dibbling technique (1.75 to 2.5 tons DM/ha per harvest at 12 weeks after planting in Ende, and 4-5 ton DM/ha in Nagekeo), followed by furrow technique covered or not covered (1-1.3 tons $\mathrm{DM} / \mathrm{ha}$ in Ende and 3.5-4 tons DM/ha in Nagekeo), and the lowest in broadcast technique (0.3-1 ton DM/ha in Ende and 2-2.5 ton DM/ha in Nagekeo). However, considering the labor requirement and cost, it was recommended that furrow technique to suit the small farmer practices in the region. Weed management showed that weeded treatment (keep legume cleaned of weeds) gave 
significantly better $(\mathrm{P}<0.05)$ biomass production compared with to that of unweeded treatment. It can be seen also that weed had more suppressing effects on Clitoria ternatea, compared to that of Lablab purpureus, especially when the plants were sown in the early wet season.

Key Words: Herbaceous Legumes, Clitoria ternatea, Centrosema pascuorum, Lablab purpureus, NTT, Planting Technique, Planting Time, Weed Management, Plant Establishment

\section{INTRODUCTION}

Legumes as fodder plants in general, including herbaceous legumes, have higher nutritive values compared to grasses (native an introduction), especially in protein content $( \pm 5-10 \%$ vs $>15-30 \%$ ) (Kana-Hau 2014; Tuna et al. 2004; Evitayani et al. 2004). Herbaceous legumes can be planted in monoculture and or in mixture (in rotation or relay with grasses or food crops of cereal). Integrating with maize crops can be done by planting when the maize has reach its flowering period (anthesis) or earlier when maize plant has just reached a man's knee hight (Nulik et al. 2013; Abera 2012). Legumes can contribute to the farming systems through their ability in fixing free $\mathrm{N}_{2}$ from the air, prevent soil erosion, reducing evaporation through soil cover (Gourley et al. 2014; Pipai et al. 2014), and provide high quality fodder and even food for human consumptions (Kana-Hau 2014; Nulik et al. 2013).

Several problems are faced when cultivating herbaceous forage legumes in East Nusa Tenggara (ENT), either in monoculture or in mixture with cereals, i.e. competition with weeds and the shortage of labor during the planting season for planting and weeding. Weeding may need upto $45 \%$ of the labor time in dryland farming systems in East Nusa Tenggara (Ngongo et al. 2005). To achieve proper forage plant establishment, several factors need to be considered and to be properly understood, i.e. technique and time of sowing, seed rate, and weed management which all are important to be understood in the dryland farming systems in ENT province.

Good establishment would expect to have good number of plant population with even distribution in the plot, which will determine good biomass production and good contribution of $\mathrm{N}$ fixation to be available for the forage itself and to the subsequent food crops planting in the integrated systems (Nulik et al. 2013). In order to determine proper techniques and time of sowing, and weed management to achieve excellent plant establishment of several selected adapted herbaceous legume species in ENT a series of experiments has been conducted between 2014/2015 and 2015/2016 in the two of three major islands in the province, i.e. Timor, and Flores. Good plant establishment is expected to provide quick land surface cover, and thus able to suppress the growth of weeds and can provide optimum biomass production in a relatively short time (3-4 months) (Nulik et al. 2013). Herbaceous legume species such as Lablab purpureus with its quick initial growth, was found to be significantly suppressed weed growth, which was grown to overcome weed invasion in coffee plantations (Santos et al. 2016).

\section{MATERIALS AND METHODS}

This experiments was conducted in a range of trials separately in several places in ENT (West Timor, and Flores), Indonesia (Table 1.), employing randomized block design, having 4 replications in the years 2015/2015 and 2015/2016.

Selected adapted herbaceous legumes were used in the experiments included: Clitoria ternatea cv Milgarra, Centrosema pascuorum cv Cavalcade dan Bundey, dan Lablab purpureus cv Highworth (Dolichos lablab). Treatments consisted of sowing techniques: (i) dibble, (ii) furrowed rows, (iii) furrowed rows covered, (iv) and broadcast combined with treatment for seed rates: (i) low (5-6 kg/ha), and (ii) high (10-12 kg/ha). Treatments of sowing time: (i) Early wet season (NovemberDecember), (ii) mid-season (February-March), and (iii) end of wet season (April-May). Sites: West Timor (Naibonat-Kupang, and So'e-TTS), and Flores (Wologai and Wolofeo in Ende, and Mbay in Nagekeo), and treatment of weed management: (i) weeded, and (ii) unweeded.

The plants were planted in plot sizes of $3 \times 4 \mathrm{~m}$ to 4 $\mathrm{x} 5 \mathrm{~m}$ depending on the availability of land for experiments at the locations stated above.

Data collected included plant population at 4 and 8 weeks after planting, and biomass production harvested at about $\geq 12$ weeks. Collected data were then analyzed using ANOVA using the software of QUASP (Queensland University Agriculture Statistical Package), at which further test of Lsd (Least significant difference test) was conducted for the difference of means. 
Table 1. Sites details, species, and experiment year

\begin{tabular}{lcccc}
\hline \hline Location & Soil type & Species & Research & Planting year \\
\hline Kupang & Sandy Vertisol & Lablab purpureus & Planting time & 2015,2016 \\
TTS & Inceptisol & Lablab purpureus & Planting time & $2014,2015,2016$ \\
Nagekeo & Inceptisol & Clitoria ternatea, Centrosema & Sowing techniques & 2015,2016 \\
& & pascuorum & & 2015,2016 \\
Ende & Volkanik & Clitoria ternatea & Sowing techniques & \\
& (Molisol) & Centrosema pascorum & & \\
\hline
\end{tabular}

\section{RESULTS AND DISCUSSIONS}

\section{Planting techniques and seed rates}

\section{Plant population}

Plant population, especially at 4 weeks after planting (in Ende), was highly significantly $(\mathrm{P}<0.001)$ affected by planting techniques (Table 2), having the highest plant population in the dibbling technique treatment (40 plants $\left./ \mathrm{m}^{2}\right)$, followed by furrowed technique and uncovered/unharrowed $\left(28 \mathrm{plants} / \mathrm{m}^{2}\right)$, then furrowed covered/harrowed or compacted (21 plants $/ \mathrm{m}^{2}$ ), while the lowest plant population was obtained in the broadcast technique $\left(9\right.$ plants $\left./ \mathrm{m}^{2}\right)$. This findings were similar to those obtained in Nagekeo experiment, where the highest plant population was achieved in the dibbling technique treatment (42 plants $\left./ \mathrm{m}^{2}\right)$, followed by furrowed and unharrowed technique (34 plants $\left./ \mathrm{m}^{2}\right)$, then furrowed and harrowed (27 plants $/ \mathrm{m}^{2}$ ), and the lowest was observed in the broadcast and harrowed (20 plants $\left./ \mathrm{m}^{2}\right)$. Nicodemo et al. (2015) obtained that highest plant population was encountered in the broadcast on land treated with harrow before and after seeds were sown (28.5 plants $\left./ \mathrm{m}^{2}\right)$ while the lowest plant number $(9.4$ plants $/ \mathrm{m}^{2}$ ) was obtained in the broadcast only technique without harrowing the land. At this we observed that the harrowed land provides good seed contact with the soil, and thus better seedling emergences.

The current findings in East Nusa Tenggara were actually often investigated in many occasions that the dibbling technique was always the best planting technique for herbaceous legumes for seedlings emergence and establishments. However there is another important factor to be considered in forage legumes planting in the region, that is the shortage of labor during the planting time, as much of labor (hired and or in the family) was concentrated in the cultivation of food crops during the season. The thought to conduct planting techniques experiment was related to the shortage of labor for planting the legumes during the planting season in the region especially if dibble planting technique is tube operated. Other reason for conducting these experiments was based on previous experience with the success of broadcasting mungbean seed for establishment after the harvest of rain fed rice in Kupang, which gave excellent results in terms of even distribution of plants and grain production (Tony Basuki, personal communication), and experience in broadcasting seeds of Centrosema pascuorum and Macroptilium atropurpureum into the land after corn was harvested (personal experience), having still some residual plant materials. Expecting that these experiences can also be achieved from the current experiments for forage legumes, having similar seed characters. However differences in the condition of the current land preparation and water erosion (surface run off), results were significantly different to that of the mungbean. The current land was cleaned from any plant materials (weeds and plant residues) thus perfect clean, while at the broadcast plating of mungbean, the land was still occupied by the stumps of the rice after harvest and some residual of the plants (straw). At mungbean broadcast trials seeds were positioned under the plant residues of rice straw or near to the stump of harvested rice plants which were able to prevent erosion by water (surface run off) and allowed proper contact with soil which all resulted in better seed germination and emergence. The plant residues and stumps also prevent the seed from the direct sunlight and thus prevent seed desiccations, as also obtained in many other experiments of seed sowing into available plant residuals i.e. in alfalfa (Medicago sativa) broadcast. While the current herbaceous legumes experiment lands were prepared by proper tillage's and proper cleaning of the lands from plant materials, which may have caused the failure of even distribution of plants as it may be affected by water erosion. Further work may be needed to broadcast into residual plants, such as rice or maize.

Actually plant population of $9-20$ seedlings $/ \mathrm{m}^{2}$ obtained in the broadcast treatments in Nagekeo should be sufficient to have good soil cover and thus biomass production, provided that the distribution was even, however because the effect of water erosion (surface run off), the distribution was not even and thus growth was not properly achieved (Figure 1) as well as biomass production. Furrowed treatment gave quite good plant 
population and distribution, and thus for the purpose of labor shortage problem can be recommended besides dibbling technique (when labor is of no restriction).

\section{Biomass Production}

Biomass production (Table 2) was best achieved when sowing was conducted in the technique of dibbling the seed $(\mathrm{P}<0.05)$ with plant population of $>40$ plants $/ \mathrm{m}^{2}$, followed by furrowed planting technique with plant population of $>22$ plants $/ \mathrm{m}^{2}$ (covered or not covered with soil), and the lowest plant population was given by the broadcast technique with plant population of 9 to 20 plants $/ \mathrm{m}^{2}$. Actually the population of 9 to 20 plants $/ \mathrm{m}^{2}$ would be sufficient for having proper land cover and biomass production, provided that the distribution was even for the species (Clitoria ternatea and Centrosema pascuorum), however the current experiment obtained uneven plant distribution on the broadcast technique (Figure 1). As the sowing technique experiment was to obtain effective and efficient planting to quickly achieve soil cover and good biomass production, especially with less labor use, where dibbling technique needs labor intensive during the planting season (December to February) when most family labor is concentrated in tending and taking care for food crops cultivation (planting and weeding).
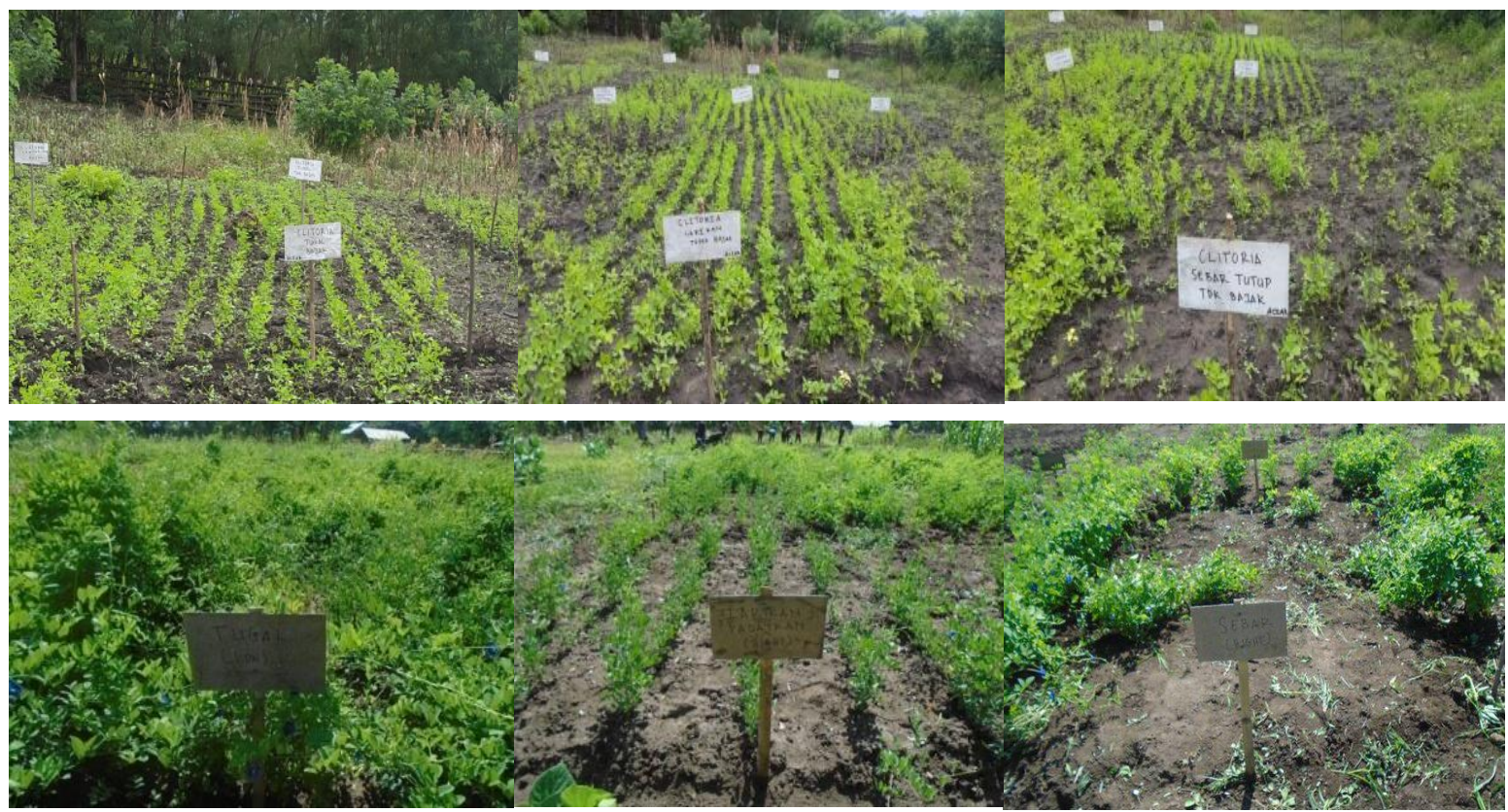

Figure 1. Plant population, distribution and soil cover in dibble sowing techniques (left: above and below), furrowed (middle: above and below) and broadcast techniques (right: above and below) of Clitoria ternatea in Nagekeo, Flores.

Table 2. Effects of sowing techniques and seed rate on the production of biomass ( $\mathrm{kg} / \mathrm{ha})$ of C. pascuorum and C. ternatea in Ende (left) planted in 2015 and Nagekeo (right) in 2016

\begin{tabular}{|c|c|c|c|c|c|c|c|c|}
\hline \multirow[b]{2}{*}{ Location } & \multirow[b]{2}{*}{ Species } & \multirow[b]{2}{*}{ Seed rate } & \multicolumn{4}{|c|}{ Sowing Techniques } & \multirow{2}{*}{\multicolumn{2}{|c|}{$\operatorname{Lsd}(5 \%)$}} \\
\hline & & & Dibbling & Furrow & $\begin{array}{l}\text { Broadcast } \\
\text { harrowed }\end{array}$ & Broadcast & & \\
\hline \multirow{4}{*}{ Ende } & \multirow{2}{*}{ C. pascuorum } & Low & 981 & 650 & 1008 & 331 & Rate & 615.7 \\
\hline & & High & 1746 & 846 & 1157 & 562 & Sowing & 870.8 \\
\hline & \multirow{2}{*}{ C.ternatea } & Low & 2386 & 1225 & 924 & 558 & Species & 615.7 \\
\hline & & High & 2603 & 1396 & 1640 & 504 & & \\
\hline \multirow{2}{*}{ Nagekeo } & \multirow{2}{*}{ C.ternatea } & Low & 4154 & 3572 & 2634 & 2563 & Rate & 930.6 \\
\hline & & High & 5086 & 4156 & 3750 & 2246 & Sowing & 1316.1 \\
\hline
\end{tabular}




\section{Sowing time}

Research conducted in Naibonat-Kupang and SoeTTS found that the best planting time for herbaceous legumes (Lablab purpureus and Clitoria ternatea) is in the early wet season (December-January). The reason for farmers in ENT to plant grain legumes (mungbean, peanut) when rain get lessen (around February to March), because the fact that when planting conducted in early wet season it will produce more vegetative materials compared to production of grain. High rainfall during vegetative growth may reduce seed production of peanut (Rahmianna et al. 2015). Mung bean is normally planted in relay method when corn is about to be harvested in the region (Murdolelono 2011). However as herbaceous forage legumes, the important part is to produce forage (leaf material) so the best planting time was in the early wet season, though planting in the mid of the wet season will also give reasonable biomass and seed production too. This will happen to the planting of legumes in the time when the maize plants have reach the adult's knee height or when maize has reached anthesis phase, which will be about the mid toward the end of the wet season (February to March), which however will produce reasonable forage amount for the purpose of effectively make use of the land and remaining soil moisture (Nulik et al. 2013).

\section{Weed Management}

Result indicated that weed investation significantly $(\mathrm{P}<0.05)$ decreased biomass production (Figure 2), especially for Clitoria ternatea than that of for Lablab purpureus. Despite that weed can affect legume biomass production, legume with quick growth (Santos et al., 2016) and of tall species (Storkey et al. 2011) can also suppress weed growth, such as Lablab purpureus, when it was used in the coffee plantation to overcome the growth of weeds.

Early wet season planting and proper seed rate were expected to give good plant establishment thus quick

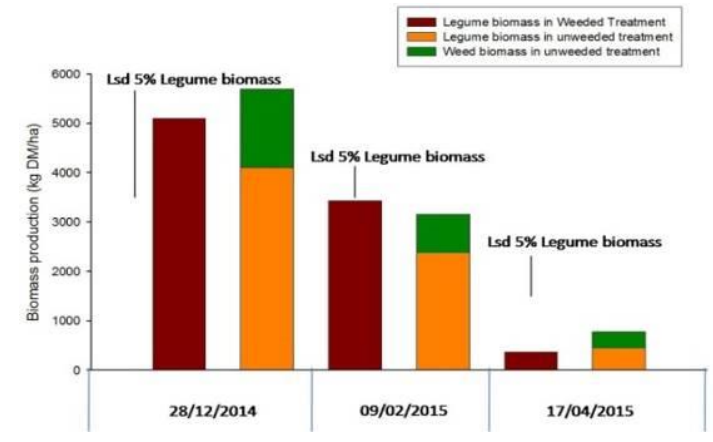

land cover to prevent weed growth and therefore less work for weeding. However, planting time and seed rate were conducted separately, thus the certainty of the combination effects on weed investation could not be concluded yet and need further experiment. Santos et al. 2016 found that Lablab purpureus showed quick establishment growth in the first year compared with Macroptilium atropurpureum (Siratro) and Arachis pintoi and thus significantly suppressed weed growth in coffee plantation, and the latter two species started to suppressed weed in the second year of their growth. Cutting management may also improve C.ternatea competition with weeds (Gomez \& Kalamani 2003). Collins \& Grundy 2005 suggested to incorporate grasses into C.ternatea in the second year to make use of the improved availability of $\mathrm{N}$ which could otherwise be taken by invaded weeds and meanwhile forcing the legume to fix more $\mathrm{N}$, as the legume will tend to stop fixing $\mathrm{N}$ in the second year when soil $\mathrm{N}$ is high. The quick growth of Lablab purpureus in the first establishment year is related to its nature characters (Valenzuela \& Smith 2002) which can produce biomass of up to 6 tons DM/ha when harvested in 3-4 months after planting (Amole et al. 2013), even up to 8 tons $\mathrm{DM} / \mathrm{ha}$ under favorable condition (good rain and soil) in the current experiment in Naibonat-Kupang.

\section{CONCLUSSION}

The best panting technique for the legumes $C$. ternatea and $C$. pascuorum is by dibbling the seed, however considering the labor shortage problem during the planting season (December - March), the practical planting technique would be by planting the seed in the rows of furrow, which should sufficiently give proper plant population. While the best planting time for forage legumes, was at the early wet season, especially if planting in monoculture for the purpose of rotational planting with cereal crops in the subsequent planting season.

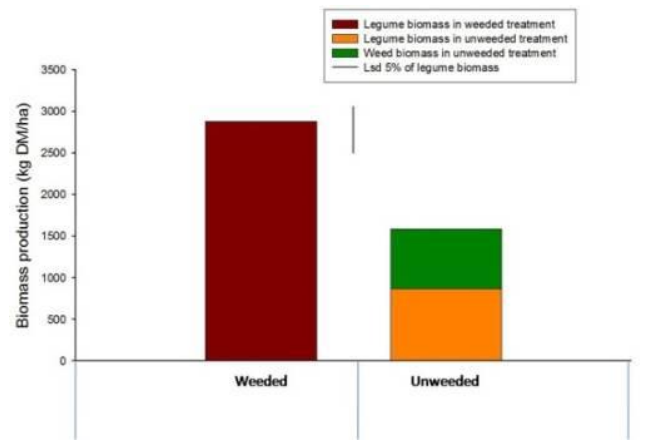

Figure 3. Effect of weed management and planting time on Lablab purpureus (left) and weed management on Clitoria ternatea (right) on biomass production. 
In order to obtain good herbaceous forage legume growth, having high biomass forage production, it is important to do weeding properly. Dibble sowing techniques gave the best plant population and biomass production in the establishment of $C$. ternatea and $C$. pascuorum with higher plant population number at 4 weeks and 8 weeks after sowing, however considering labor shortage during the planting season, it would be better to recommend furrow planting technique (harrowed and not harrowed). Moreover there is a need to pursue more on the broadcast technique under condition of land having plant residues for its benefit in better seed contact with soil and prevention of water erosion (surface run off) that may wash away the seed after sowing.

\section{ACKNOWLEDGEMENT}

The experiments were parts activities of the collaborate forage research project of ACIAR and BPTP NTT on project number LPS/2012/064, thus thanks are directed to ACIAR, BPTP NTT, research colleges form Australia: Dr. Linsay Bell (CSIRO Australia), Dr. Kendrick Cox (QDPI Australia), and to the field research staff of ACIAR in ENT: Yanto Liunokas (site of TTS), Yendri Abi (site of Kupang), Yakobus Uran (site of Ende), and R. Rebo (site of Nagekeo).

\section{REFERENCES}

Abera M. 2012. The effect of under sowing of forage legumes in maize on dry matter yield and nutritional value of the fodder in Baresa Watershed, Ethiopia. Int J Sci Res. 3:1070-1077.

Amole TA, Oduguwa BO, Shittu O, Famakinde A, Okwelum N, Ojo VOA, Dele PA, Idowu OJ, Ogunlolu B, Adebiyi AO. 2013. Herbage yield and quality of Lablab purpureus during the late dry season in western Nigeria. Slovak J Anim Sci. 46:22-30.

Collins R, Grundy T. 2005. The butterfly pea book: a guide to establishing managing butterfly pea in coastal Queensland. Queensland Government Department of Primary Industries and Fisheries. 64 pages.

Evitayani, Warly L, Fariani A, Ichinohe T, Fujihara T. 2004. Study on nutritive value of tropical forages in North Sumatra, Indonesia. Asian-Aust J Anim Sci. 17:15181523 .

Gomez SM, Kalamani A. 2003. A nutritive multipurpose forage legume for the Tropics - An overview. Pak J Nutr. 2:374-379.
Gourley CJP, Aarons SR, Hannah MM. 2014. The contribution of pasture legumes to nitrogen inputs and milk production on dairy farms in Australia. Proceedings of 17th Australian Nitrogen Fixation Conference. Adelaide (Australia). p. 19-20.

Kana-Hau D. 2014. The potency to use and develop local and introduced herbaceous legume forages in East Nusa Tenggara. Subandriyo, Kusmartono, Santosa KA, Kurnianto E, Purnomoadi A, Sodiq A, Wiryawan KG, Darodjah S, Inounu I, Darmono, Priyanti A, Wynn P, Han JL, Tay-Hsu J, Idrus Z, editors. Proceedings the 16th AAAP Congress. Yogyakarta (Indones): Gadjah Mada University. p. 2710-2713.

Murdolelono B. 2011. Teknologi tanaman kacang-kacangan untuk petani di Nusa Tenggara Timur. Prosiding Seminar Hasil Penelitian Tanaman Aneka Kacang dan Umbi. p. 825-835.

Nicodemo MLF, de Zousa FHD, Pezzopane JRM, Mendes JCT, Junior WB. 2015. Establishment techniques for tropical in the understory of an eucalyptus plantation. Revista Árvore, Viçosa-MG. 39:345-352.

Ngongo Y, Ataupah H, Lidjang IK, Hosang EY, 2005. Studi ancangan sosial budaya menunjang percepatan adopsi dan difusi inovasi pertanian di Timor Barat. RUT II, Kerjasama Proyek P3NT/Litbang Pertanian dengan Kementerian Negara Ristek.

Nulik J, Dalgliesh N, Cox K, Gabb S. 2013. Integrating herbaceous legumes into crop and livestock systems in Eastern Indonesia. ACIAR Monograph No. 154. 130 pages.

Pipai R, McNeill A, Unkovich M, Banabas M, Nelson P. 2014. Biological nitrogen fixation by legume cover plants in oil palm plantations. Proceedings of 17th Australian Nitrogen Fixation Conference. Adelaide (Australia). p. 21-22.

Rahmianna AA, Pratiwi H, Hernowo D, 2015. Budidaya Kacang Tanah. Balai Penelitian Tanaman Aneka Kacang dan Umbi. Monograf Balitkabi No. 13: 133169.

Santos JCF, da Cunha AJ, Ferreira FA, Santos RHS, Sakiyama NS, de Lima PC. 2016. Herbaceous legumes intercropping in weed management of the coffee crop. J Agr Environment Sci. 5:91-100.

Storkey J, Doring T, Baddeley J, Marshall A, Roderick S, Jones H. 2011. Modelling the ability of legumes to suppress weeds. Aspec App Biol. 109:53-58.

Tuna C, Coskuntuna L, Koc F. 2004. Determination of Nutritive value of some legume and grasses. Pak J Biol Sci. 7:1750-1753.

Valenzuela H, Smith J. 2002. Lablab. Honolulu (HI): University of Hawaii. 3 p. (Sustainable Agriculture; SAGM-7). 